\title{
ANÁLISE DA ASSOCIAÇÃO ENTRE POLIMORFISMOS NO GENE DO VDR E A SUSCETIBILIDADE À DOENÇA RENAL CRÔNICA E À PERIODONTAL
}

Cleber Machado SOUZA, Ana Paula Paula BRAOSI, Sônia Mara LUCZYSZYN, Roberto PECOITS-FILHO, Paula Cristina TREVILATTO

Doença renal crônica (DRC) (ROMÃO JR, 2004) e doença periodontal (DP) (PAGE, 1997) são problemas de saúde-pública, sendo esta última negligenciada na população de renais crônicos (NAUGLE, 1998; GAVALDA, 1999; ATASSI, 2002; DURAN, 2004). Vitamina D é um hormônio que interage com o seu receptor nuclear (VDR) regulando ampla variedade de processos biológicos, que incluem metabolismo ósseo, modulação da resposta imune e a transcrição de genes envolvidos nos mecanismos básicos da DRC e da DP (HOLICK, 2004). O objetivo deste trabalho foi de investigar a associação entre polimorfismos no gene do VDR e a suscetibilidade à DRC e à DP. 222 indivíduos foram divididos em quatro grupos: 59 sem DRC e sem DP (grupo 1); 50 sem DRC e com DP (grupo 2), selecionados da Clínica Odontológica da PUCPR; 50 com DRC, em hemodiálise, sem DP (grupo 3), e 63 com DRC, em hemodiálise, e com DP (grupo 4), selecionados na Fundação Pró-Renal. Os polimorfismos Taql e Bsml do gene do VDR (MIYAMOTO, 1997; BRETT, 2005) foram analisados pela técnica de PCR-RFLP. O alelo G foi associado com a proteção contra a DRC. Nenhuma associação foi observada entre os polimorfismos estudados e a suscetibilidade/proteção a DP (DE BRITO JR, 2004). 